\title{
(6) Political impediments to a tobacco endgame
}

\section{OPEN ACCESS}

Gerald R. Ford School of Public Policy, University of Michigan, Ann Arbor, Michigan, USA

\section{Correspondence to}

Professor Barry George Rabe, Gerald R. Ford School of Public Policy, University of Michigan, 735 S. State Street, Ann Arbor, MI 48109, USA;

brabe@umich.edu

Received 25 September 2012 Revised 21 November 2012 Accepted 20 December 2012

\section{Barry George Rabe}

\section{ABSTRACT}

Any serious consideration of exploring a tobacco endgame in the USA must build upon the enviable track record of reducing tobacco use through a mixture of federal and state policies. This foundation may pose particular challenges in approaching an endgame, including questions of national political feasibility, public support, limitations of sub-federal experimentation and recruitment of future political champions. Advocates must demonstrate a compelling need for a dramatic expansion beyond existing efforts, amid competition from alternative issues and little apparent public appetite for such an initiative.

Tobacco control represents one of the more successful arenas of American public policy over the past quarter-century. Major political impediments have been surmounted at all governmental levels, generating an array of regulatory and taxation policies that are widely seen as contributing to significant tobacco use reductions among Americans. Any consideration of shifting toward a tobacco endgame will build on that established record while confronting major political hurdles. Indeed, prior success may only complicate the challenge of seriously pursuing such goals.

\section{AN ENVIABLE TRACK RECORD}

Tobacco control epitomises, in many respects, a textbook example of how to frame a public health issue to sustain an ever-expanding set of policy interventions over multiple decades. This has included a systematic assault on the 'powerful sub-system' of the industry and its once-impregnable coalition of tobacco growers, manufacturers and consumers, as well as the mixture of federal and state executive agencies and legislative committees that have coalesced around them. ${ }^{1}$ Advocates have strategically and relentlessly advanced scientific evidence of the health risks linked to product use; they have undertaken one of the most aggressive and creative advocacy campaigns based on moral opprobrium witnessed in the past century. Having steadily weakened governing coalition cohesion, they have exploited the numerous opportunities that American federalism affords for venue-shopping and planted new policy experiments in friendly jurisdictions while promoting horizontal diffusion wherever feasible. $^{2}$ They then used these experiences to drive federal-level reforms when windows of opportunity emerged in Washington, DC.

This far-reaching political assault on tobacco use has involved the use of a diverse array of policy tools, including hundreds of local smoking bans, aggressive litigation by state attorneys general, 110 tobacco excise tax increases in 47 states since 2000 and far-reaching federal legislation expanding regulatory and taxation powers. It has also established a considerable track record of outcomes, reflected in a monumental master settlement and a major decline in product use over the past several decades. Approximately 20\% of American adults smoke at present, reflecting a rate that has declined by more than half since the 1960s, but has stabilised more recently. ${ }^{3}$

Few areas of domestic policy feature such an extensive transformation. Indeed, the vast majority of American tobacco policies have moved into advanced implementation and even expanded, unlike many domestic reforms that have narrowed or been reversed over time. ${ }^{4}$ It is not evident, however, that this extraordinary record necessarily positions tobacco control for serious pursuit of endgame strategies in the coming decades. Several potential hurdles confront any substantive effort to place endgame proposals on the American political agenda for meaningful consideration, much less to institutionalise them in Washington or in state capitals.

\section{SUBSTANTIAL POLITICAL IMPEDIMENTS}

First, it is hard to envision any future Congress bridging its sharp divides to embrace a tobacco endgame. This is problematic because any meaningful American engagement of such goals would be likely to entail new federal legislation, given the limitations of subfederal policy and the fragility of unilateral federal executive branch actions. However, tobacco control has witnessed only 'occasional bursts of federal activity' and does not appear particularly well poised to elevate its standing on future congressional agendas. ${ }^{5}$ The 2009 Family Smoking Prevention and Tobacco Control Act emerged from a near-perfect storm of political circumstances that are unlikely to be replicated anytime soon. For advocates to raise the issue successfully into a congressional priority, they would probably have to explain why this historic legislation was inadequate, while making a compelling case to elevate tobacco elimination over a range of other issue claimants and also persuading legislators to forego an attractive source of campaign funding. If anything, the well-known hurdles imposed by the American separation-of-powers system have only been exacerbated by the emergence of deeply polarised political parties that increasingly operate in ways that are consistent with a parliamentary system. ${ }^{67}$ This phenomenon undermines the political prospects for any serious legislative proposal, with each previously advanced endgame option posing its own unique challenges for securing future congressional uptake.

Second, there are enormous constraints on any efforts to try to launch major federal policies solely through executive branch initiatives. Federal agency entrepreneurship does offer one potential alternative, with ample American precedent for an 'administrative presidency' approach designed to expand executive branch powers through agency 
reinterpretation of existing statutes. The Food and Drug Administration would be most likely to assume the lead role in such case, probably through an expansive reading of its powers under the 2009 legislation. This strategy has long faced considerable hurdles, however. It presumes not only strong and sustainable agency leadership, but also steadfast support from multiple presidents, no congressional backlash, successful deflection of inevitable court challenges and robust public support. This is hardly a reliable formula for transformational policy. ${ }^{8}$

Third, no evidence suggests that the American public has an appetite for an all-out assault on tobacco use. Public opinion research demonstrates considerable support for such interventions as restaurant and workplace smoking bans, reflecting historically strong public trust in the science linking smoking with profound public health risks. ${ }^{9}$ But public support for far more expansive tobacco control is, at best, unclear. None of the standardised public opinion instruments that annually ask Americans to rank their top policy priorities have given any hint in recent decades that a major added assault on tobacco control is on the radar screens of American citizens, much less any sort of a priority. We have little data from longitudinal studies applicable to this issue, although Gallup has been asking Americans whether or not smoking should be made 'totally illegal' for nearly two decades, with support ranging from $11 \%$ to $17 \%$ since $1994 .{ }^{10}$ Though this question may be reframed to elevate support levels, it is hard to envision anyone other than leaders of the tobacco control advocacy community as eager to make an endgame assault a central American policy priority. Indeed, analysts have noted that 'it is rare for there to be a clamour for comprehensive measures to restrict tobacco,' (page 124 of reference 5) just as other studies have concluded that tobacco control 'often failed to ignite the passions' of elected officials and citizens. ${ }^{11}$

Fourth, bold policy options that appeal to one state or a cluster of states often fail to diffuse nationally. American federalism may again be a fruitful proving ground for competing endgame proposals, beginning with modest experimentation in potentially friendly venues. But this suggests, at most, an extensive period of experimentation that would ultimately require federal government acceptance. States and regions continue to diverge in their receptivity to tobacco control policy initiatives, with resistance particularly evident in Southern states that have experienced enormous population growth in recent decades. This is illustrated in tremendous inter-state differentiation in cigarette excise taxes. Although states averaged $\$ 1.49$ per pack in 2012, rates exceeding $\$ 3$ per pack existed in such states as Connecticut and New York alongside rates lower than 40 cents per pack in such states as Virginia and Georgia. Such variability is also evident in numerous other state tobacco policies, indicating that states remain fertile venues for initial experimentation, but that prospects for universal diffusion are unlikely without federal uptake.

Fifth, it is not clear that tobacco control can continue to attract political champions willing to maintain the issue's preeminence or to serve as policy entrepreneurs. From Benjamin Rush during the American republic's founding to Henry Waxman and Michael Bloomberg more recently, political figures have found tobacco control politically attractive and have proven adept at demonising opponents in pursuing policy goals. ${ }^{12}{ }^{13}$ Championing tobacco control may be particularly attractive when no comparable public health issues exist on the agenda and the likely beneficiaries of reduced tobacco use represent a large population transcending social and class boundaries. But it may be less appealing politically as the number of users and potential victims not only decline but increasingly reflect societal sectors with sub-average levels of education, income and capacity to engage the political process. American political elites may well have decreasing contact with individuals who smoke, thereby reducing the saliency or career advancement allure attached to championing endgame strategies. ${ }^{14}$

Concomitantly, the heightened saliency of obesity as an issue threatens the moral high ground occupied by tobacco control in public health policy circles. Obesity offers striking parallels to the early American anti-tobacco campaign, featuring disturbing evidence about health consequences, clear links to consumption of legal and subsidised products, and significant spikes in media coverage and policy proposals. With obesity rates soaring and tobacco use rates declining from prior decades, its ascension suggests the possible marginalisation of tobacco. Indeed, many of the American elected federal officials who are most active on the tobacco control front are among the most senior members of the Senate and House, and it is difficult to identify successful candidates for federal and state office in the 2010 or 2012 elections who have emerged as the 'next generation' of tobacco control policy entrepreneurs.

\section{AN INCREMENTAL PROPOSAL}

The early exploration of endgame strategies for tobacco control might also benefit from a careful review of all existing policies, as new permutations might present significant opportunities. One such exploration might entail revisitation of federal and state tobacco excise taxes, where tobacco occupies unique territory in sustaining support across partisan and regional cleavages for remarkably steep increases. Three strategies emerging from other excise tax arenas, such as energy, may warrant consideration. First, tighter linkage between cost imposition and fund usage can bolster political support and sustain supportive programmes, perhaps beginning with proposals to connect excise taxes with tobacco control programmes better. ${ }^{15}$ Second, tax rates are increasingly being varied as applied to seemingly comparable products that, in fact, pose differential risks, thereby providing more nuanced price signals to potential consumers. This may afford particular opportunities in the tobacco arena, given the emergence of products that may pose less health risk than conventional products. Third, intergovernmental revenue transfer has increasingly focused on rewarding high performance levels by states and localities, encouraging them to 'race to the top'. ${ }^{16}$ Imagine if states with very low smoking rates, such as Utah and California, received supplemental federal transfer dollars from excise taxes, whereas high-use states, most notably in the South, lost significant funding. While none of these options would swiftly move America into any endgame, they might accelerate this transition more rapidly than the pursuit of policy initiatives seeking transformational outcomes.

\section{Competing interests None.}

Provenance and peer review Not commissioned; externally peer reviewed.

Open Access This is an Open Access article distributed in accordance with the Creative Commons Attribution Non Commercial (CC BY-NC 3.0) license, which permits others to distribute, remix, adapt, build upon this work non-commercially, and license their derivative works on different terms, provided the original work is properly cited and the use is non-commercial. See: http://creativecommons.org/ licenses/by-nc/3.0/

\section{REFERENCES}

1 Baumgartner FR, Jones BD. Agendas and Instability in American Politics. Chicago: University of Chicago Press, 1993.

2 Shipan CR, Volden C. Bottom-up federalism: the diffusion of antismoking policies from U.S. cities to states. Am J Political Sci 2006;50:825-43.

3 Warner KE, Mendez D. Tobacco control policy in developed countries: yesterday, today, and tomorrow. Nicotine Tob Res 2010;12:876-87. 
4 Patashnik EM. Reforms at Risk: What Happens after Major Policy Changes are Enacted. Princeton: Princeton University Press, 2008.

5 Cairney P, Studlar DT, Mamudu H. Global Tobacco Policy: Power, Policy, Governance and Transfer. London: Palgrave Macmillan, 2012.

6 Mann TE, Ornstein NJ. It's Even Worse Than it Looks: How the American Constitutional System Collided with the New Politics of Extremism. New York: Basic Books, 2012.

7 Mann TE, Ornstein NJ. The Broken Branch: How Congress is Failing America and How to Get it Back on Track. New York: Oxford University Press, 2006.

8 Sollenberger MA, Rozell MJ. The President's Czars: Undermining Congress and the Constitution. Lawrence, KS: University Press of Kansas, 2012.

9 Pacheco J. Trends—public opinion on smoking and anti-smoking policies. Public Opin Q 2011;75:576-92.

10 Jones JM. Majority disapproves of new law regulating tobacco: only a small minority believes smoking should be made illegal in the United States. New York: Gallup, 2009. www.gallup.com/poll/121079/majority-disapproves-new-law-regulatingtobacco.aspx (accessed 3 Sep 2012).
11 Jacobson PD, Wasserman J. Tobacco Control Laws: Implementation and Enforcement. Santa Monica: Rand, 1997:xvii.

12 Morone JA. Hellfire Nation: the Politics of Sin in American History. New Haven: Yale University Press, 2006.

13 Derthick MA. Up in Smoke: from Legislation to Litigation in Tobacco Politics. 3rd edn. Washington, DC: CQ Press, 2012.

14 Teodoro MP. Bureaucratic Ambition: Careers, Motives, and the Innovative Administrator. Baltimore: Johns Hopkins University Press, 2007.

15 Rabe BG, Borick CP. Carbon taxation and policy labeling: experiences from American states and Canadian provinces. Rev Policy Res 2012:29:359-82.

16 Rabe BG. Racing to the top, the bottom, or the middle of the pack? The evolving state government role in environmental protection. In: Vig NJ, Kraft ME, eds. Environmental Policy: New Directions for the 21st Century. 8th edn. Washington, DC: CQ Press, 2013:30-53. 